\title{
Nerve Growth Factor Induces Transcription of the p21 WAF1/CIP1 and Cyclin D1 Genes in PC12 Cells by Activating the Sp1 Transcription Factor
}

\author{
Guo-Zai Yan and Edward B. Ziff \\ Howard Hughes Medical Institute, Department of Biochemistry, Kaplan Cancer Center, New York University Medical \\ Center, New York, New York 10016
}

\begin{abstract}
The PC12 pheochromocytoma cell line responds to nerve growth factor (NGF) by gradually exiting from the cell cycle and differentiating to a sympathetic neuronal phenotype. We have shown previously (Yan and Ziff, 1995) that NGF induces the expression of the p21 WAF1/CIP1/Sdi1 (p21) cyclin-dependent kinase (Cdk) inhibitor protein and the $G_{1}$ phase cyclin, cyclin D1. In this report, we show that induction is at the level of transcription and that the DNA elements in both promoters that are required for NGF-specific induction are clusters of binding sites for the Sp1 transcription factor. NGF also induced a synthetic promoter with repeated $\mathrm{Sp} 1$ sites linked to a core promoter, and a plasmid regulated by a chimeric transactivator
\end{abstract}

PC12 cells, a neural crest-derived pheochromocytoma cell line (Greene and Tischler, 1976), responds to the neurotrophin nerve growth factor (NGF) by withdrawing from the cell cycle, extending neurites, and changing from chromaffin-like cells to cells that resemble sympathetic neurons (Unsicker et al., 1978; Aloe and Levi, 1979; Anderson and Axel, 1986). Both NGF and a second growth factor, epidermal growth factor (EGF), activate the MAP kinase pathway via receptor tyrosine kinases (Gomez et al., 1990; Gotoh et al., 1990; Boulton et al., 1991; Gomez and Cohen, 1991) and induce early and delayed early response genes (Greenberg et al., 1986; Leonard et al., 1987; Gizang and Ziff, 1990). EGF, in contrast, is a weak mitogen (Greene and Tischler, 1976; Boonstra et al., 1983). NGF selectively induces both sustained MAP kinase pathway activity (Traverse et al., 1992) and expression of late genes, including the peripherin gene (Leonard et al., 1987, 1988), coinciding with the onset of differentiation and the arrest of growth.

NGF induces dramatic changes in the PC12 cell cycle machinery, including the expression of cyclin $D 1$, a $G_{1}$ phase cyclin (Buchkovich and Ziff, 1994; Dobashi et al., 1995; Yan and Ziff, 1995; van Grunsven et al., 1996b), and of p21 WAF1/CIP1/Sdi1

\footnotetext{
Received March 4, 1997; revised April 25, 1997; accepted June 4, 1997.

This work was supported by Research Grant MV75 from the American Cancer Society. G.-Z.Y. was an associate and E.B.Z. is an investigator of the Howard Hughes Medical Institute. We thank C. Sherr for the cyclin D1 cDNA clone, D. Beach for the p21 cDNA clone, X.-F. Wang for the p21p, p21p $\Delta 1.1, \mathrm{p} 21 \mathrm{pSma} \Delta 1$, and p21pSma $\Delta 2$ plasmids, T. Gilmore for the JDG and JDG + Sp1N plasmids, and R. Tjian for the G6TI-CAT and G3TI-CAT plasmids. We thank Drs. N. Tanese and M. Pagano for helpful discussions of Sp1 and cyclin D1 function, M. Datto for discussions of the p21 promoter, and C. Daly, P. Issack, and M. Ghee for critical readings of this manuscript.

Correspondence should be addressed to Edward B. Ziff, Howard Hughes Medical Institute, New York University Medical Center, Department of Biochemistry, 550 First Avenue, New York, NY 10016.

Copyright (C) 1997 Society for Neuroscience $\quad 0270-6474 / 97 / 176122-11 \$ 05.00 / 0$
}

in which the Gal4 DNA binding domain is fused to the Sp1 transactivation domain, indicating that this transactivation domain is regulated by NGF. Epidermal growth factor, which is a weak mitogen for PC12, failed to induce any of these promoter constructs. We consider a model in which the PC12 cell cycle is arrested as p21 accumulates and attains inhibitory levels relative to $\mathrm{Cdk} /$ cyclin complexes. Sustained activation of p21 expression is proposed to be a distinguishing feature of the activity of NGF that contributes to PC12 growth arrest during differentiation

Key words: NGF; cyclin D1; p21 WAF1/CIP1/Sdi1; Sp1; cell cycle; PC12 (p21), a cyclin-dependent kinase (Cdk) inhibitor (Yan and Ziff, 1995; van Grunsven et al., 1996b), which is also induced by the p53 tumor suppressor protein (El-Deiry et al., 1993; Dulic et al., 1994). NGF also gradually decreases the activities and protein levels of $\mathrm{Cdc} 2$ and $\mathrm{Cdk} 2,-4$, and -6 and decreases the level of cyclin B2 (Buchkovich and Ziff, 1994; Yan and Ziff, 1995). Cyclin D1 and p21 exert opposing effects on cell cycling. Cyclin D1 accelerates cell transit through the $G_{1}$ phase by forming complexes with $\mathrm{Cdk} 4$ and $\mathrm{Cdk} 6$, which phosphorylate the retinoblastoma protein $\mathrm{Rb}$ (for review, see Sherr, 1995), blocking the function of $\mathrm{Rb}$ as a repressor of genes required for cell proliferation (for review, see Chen et al., 1995b; Beijersbergen and Bernards, 1996). The p21 protein inhibits the Cdk4/D1 and Cdk6/D1 complexes and thereby maintains the hypophosphorylated repressor state of $\mathrm{Rb}$ that blocks $\mathrm{S}$ phase entry. A high stoichiometric ratio of $\mathrm{p} 21$ to $\mathrm{Cdk}$ is required for kinase inhibition (Zhang et al., 1994). Thus, the relative levels of expression of p21, Cdk4/D1, and Cdk6/D1 may determine the proliferative state of the cell.

In this report we show that NGF selectively activates the p21 and cyclin D1 promoters by stimulating the transactivation domain of Sp1, a zinc finger transcription factor (Kadonaga et al., 1987) that binds adjacent to the TATA box of the p21 and cyclin D1 gene promoters. We discuss the significance of NGF stimulation of the p21 and cyclin D1 promoters for the mechanism of PC12 differentiation by NGF, including the possible role of cyclin $\mathrm{D} 1, \mathrm{G}_{1}$ cyclin, in a program leading to growth arrest.

\section{MATERIALS AND METHODS}

Determination of cell number and neurite extension. Growth of PC12 cells was determined by counting the nuclei using a hemacytometer (Soto and Sonnenschein, 1985). Nuclei were isolated by lysing cells in lysis buffer (0.1\% PBS, $0.5 \%$ Triton X-100, 2 mM $\mathrm{MgCl}_{2}, 0.5 \%$ ethylhexadecyldimethylammonium bromide). 
The differentiation state of PC12 cells was determined by counting neurite-bearing cells with neurite length at least twice that of the cell body (Boulukos and Ziff, 1993). The level of neurite extension was calculated as the percentage of neurite-bearing cells relative to the total number of cells analyzed.

Isolation of rat cyclin D1 genomic DNA, Southern blot, and DNA sequence analysis. A rat genomic library cloned in $\chi$ DASH II vector (Stratagene, La Jolla, CA) was screened with the full-length mouse cyclin D1 cDNA (Matsushime et al., 1991). Of 1 million phage plaques screened, 7 positive plaques were isolated. Four positive phages with cyclin D1 inserts in size ranging from $20 \mathrm{~kb}$ to $10 \mathrm{~kb}$ were further characterized by Southern blot analysis. Phage DNA was purified with PEG 6000 and digested with restriction enzymes. DNA samples fractionated on $1 \%$ agarose gels were transferred to nylon membrane (Schleicher \& Schuell, Keene, $\mathrm{NH}$ ) after denaturing in $1.5 \mathrm{M} \mathrm{NaCl}, 0.5 \mathrm{M} \mathrm{NaOH}$ for $45 \mathrm{~min}$. A $1.3 \mathrm{~kb}$ full-length or a $500 \mathrm{bp}$ PstI-fragment cDNA was used as the probe. Hybridization was performed at $55^{\circ} \mathrm{C}$ in QuikHyb Buffer (Stratagene, La Jolla, CA). A $5.0 \mathrm{~kb}$ NotI/XbaI-fragment was subcloned into pBSKS. For sequencing of the $5^{\prime}$ upstream region, the $5.0 \mathrm{~kb}$ of prCD1-5000 was digested with SmaI. A 1660 bp fragment of prCD1-1414 was sequenced in both directions by Dr. B. Goldschmidt (Skirball Institute, New York University Medical Center) (1660 bp sequence submitted to GenBank database).

Northern blot analysis and Western blot analysis. Total RNA was prepared by the LiCl-guanidinium isothiocyanate method (Cathala et al., 1983). Samples $(15 \mu \mathrm{g})$ of total RNA were separated by formaldehyde gel electrophoresis and transferred to nylon membrane (Schleicher \& Schuell). Expression of p21 or cyclin D1 mRNA was measured by hybridization with the human p21 probe or mouse cyclin D1 probe, respectively. Probes were labeled by random priming (Boehringer Mannheim, Indianapolis, IN), and hybridization and washing were performed under standard conditions. Autoradiograms were scanned with an EPSON Expression 636 scanner. Ribosomal RNA was visualized by ethidium staining as a loading control. Western blotting has been described previously (Yan and Ziff, 1995). The Sp1 antibodies (Santa Cruz Biotechnology, Santa Cruz, CA) were raised against a synthetic peptide (PEP2) corresponding to amino acid residues 520-538 of the Sp1 protein.

Constructs. The luciferase reporter plasmids containing various deletions of the p21 promoter sequence (Datto et al., 1995a,b) were gifts from Dr. Xiao-Fang Wang (Duke University, Durham, NC). Restriction sites in the rat cyclin D1 sequence were used to subclone a series of $5^{\prime}$ upstream deletion constructs (see Fig. 2). The initial cyclin D1 construct prCD1-5000 was cloned by digesting the $5.0 \mathrm{~kb}$ fragment from pBSKS5.0 with $B g l \mathrm{I} / N o t \mathrm{I}$ and inserting the resulting $1810 \mathrm{bp}$ fragment upstream of the luciferase gene of the pGL2-basic reporter construct (Promega, Madison, WI). Deletions of sequences down to -450 were generated from the prCD1-1810 plasmid by removing different fragments from the 5 ' end using specific restriction sites followed by blunt end religation: prCD1-1414, -1414 to +227 (SmaI/MluI); prCD1-980, -980 to +227 (HindIII/MulI); prCD1-450, -450 to +227 (PmlI/MulI). The deletions prCD1-70, prCD1-10, and prCD1 $\Delta-450$ were generated via PCR using specific primers with additional restriction sites for insertion into the pGL2-basic vector. G6TI-Luc and G3TI-Luc were constructed from plasmids G6TI-CAT and G3TI-CAT (gift of Dr. Robert Tjian, University of California, Berkeley) by replacing the CAT gene with the luciferase gene by digestion with KpnI/BamHI. GTI-Luc was generated by digesting G6TI-Luc with SalI and religation. PCR was used to generate Gal4 (1-147) or Gal4 Sp1N (Gal4 1-147+Sp1N 83-621) by using pJDG or pJDG + Sp1N (provided by Thomas Gilmore, Boston University) (Sif and Gilmore, 1994) as template for DNA amplification. These PCR fragments were cloned into the HindIII/XbaI site of pRcRSV expression vector to yield Rc-Gal4 or Rc-Gal4-Sp1N.

Cell culture and transfection of PC12 cells. PC12 cells were cultured on collagen-coated dishes. For experiments involving NGF or EGF induction, previously described procedures for $\mathrm{PC} 12$ cell culture and high efficiency polycationic liposome transfection were used (Yan and Ziff, 1995). All transfections included the plasmid RSV- $\beta$ gal as an internal control for transfection efficiency. When the amount of an expression vector was varied, the quantity of vector plasmid was held constant by the addition of empty vector plasmid DNA. NGF or EGF was added $12 \mathrm{hr}$ after removal of the lipid-nucleic acid complex. The cells were harvested $72 \mathrm{hr}$ after transfection for assay of luciferase or $\beta$-galactosidase or CAT activity as described below. Luciferase activity was corrected for differences in transfection by normalization to $\beta$-galactosidase levels as fol- lows. The level of $\beta$-galactoside in cells from each transfection $\left(G_{i}\right)$ was measured, and the average of the $\beta$-galactosidase levels $\left(\mathrm{G}_{\mathrm{av}}\right)$ for all of the transfections in one experiment was calculated. The luciferase light units of luciferase enzyme expressed in individual transfections $\left(\mathrm{L}_{\mathrm{i}}\right)$ was normalized to give the normalized light units $\left(\mathrm{L}_{\text {norm }}\right)$ according to the formula:

$$
L_{\text {norm }}=L_{\mathrm{i}}\left(G_{\mathrm{av}} / G_{\mathrm{i}}\right) \text {. }
$$

The "fold induction," which is the number of normalized light units expressed in a growth factor-treated culture of cells divided by the number of normalized light units in the control culture is also presented. Luciferase, $\beta$-galactosidase, and CAT assay. Luciferase and $\beta$-galactosidase assays were performed essentially as described (L. Li et al., 1994). CAT assays were performed with the FAST CAT Green (deoxy) Chloramphenicol Acetyltransferase Assay system (Molecular Probes, Eugene, OR) according to the manufacturer's protocol. The CAT enzymatic reaction was performed with a $5 \mathrm{hr}$ incubation at $37^{\circ} \mathrm{C}$. CAT activity was determined as the percentage acetylated chloramphenicol relative to the total of the acetylated and unacetylated chloramphenicol.

Nuclear extract preparation and electrophoretic mobility shift assays (EMSAs). PC12 nuclear extracts were prepared from unstimulated and NGF-stimulated cell cultures grown as described above. Nuclear extracts from PC12 cells were prepared essentially as described by Dignam et al. (1983). Protein concentrations were determined by using the Bio-Rad protein assay kit (Bio-Rad, Richmond, CA). Oligodeoxynucleotides were synthesized and purified by OPERON Inc. The sequences of the wildtype or mutant Sp1 binding site oligonucleotide used in these experiments were 5'-ATTCGATCGGGGCGGGGCGAG-3' and 5'ATTCGATCGGTTCGGGGCGAG-3', respectively. Complementary oligonucleotides were annealed and labeled at their $5^{\prime}$ ends, using $[\gamma-32$ p]ATP $(3000 \mathrm{Ci} / \mathrm{mmol})$ and T4 polynucleotide kinase (Promega). Radiolabled double-stranded oligonucleotides were purified through a Sephadex G-25 spin column. DNA-protein binding analysis was performed as follows. Each reaction containing $10 \mathrm{mM}$ Tris- $\mathrm{HCl}, \mathrm{pH} 7.5,40$ $\mathrm{mm} \mathrm{NaCl}, 1 \mathrm{~mm} \mathrm{MgCl}{ }^{2}, 1 \mathrm{~mm}$ EDTA, $1 \mathrm{~mm}$ dithiothreitol, 5\% glycerol, $2 \mu \mathrm{g}$ of poly $(\mathrm{dI}-\mathrm{dC})$, and $10 \mu \mathrm{g}$ of nuclear extracts in a total reaction volume of $10 \mu \mathrm{l}$ was incubated at room temperature for $20 \mathrm{~min}$. Then 1 ng of labeled probe $\left(5-10 \times 10^{4} \mathrm{cpm}\right)$ was added, and the incubation continued for $15 \mathrm{~min}$. For competition studies, 100 -fold molar excess of unlabeled oligonucleotides was added to the reaction mixture before the addition of radiolabeled probe, and the mixture was incubated at room temperature for $20 \mathrm{~min}$. Supershift assays were performed as described above, with the exception that subsequent to incubation of oligonucleotide probes with nuclear extracts, $1.0 \mu \mathrm{l}$ of TransCruz gel supershift antibody against $\mathrm{Sp} 1$ protein $(1.0 \mathrm{mg} / \mathrm{ml})$ (Santa Cruz) was added to the reaction mixture and incubated for $45 \mathrm{~min}$ at room temperature. Mobility shift reactions were resolved on $4 \%$ nondenaturing polyacrylamide gels that were electrophoresed at $100 \mathrm{~V}$ at room temperature for 3-4 hr. Gels were then dried and exposed to x-ray film with an intensifying screen at $-70^{\circ} \mathrm{C}$. Autoradiograms were scanned with EPSON Expression 636 scanner.

\section{RESULTS}

We first established that PC12 cells differentiated under our conditions of treatment with NGF. When asynchronous PC12 cells were cultured in the presence or absence of NGF, the cells slowed division and underwent neuronal differentiation. Although the number of cells in a control culture lacking NGF continued to increase over a $14 \mathrm{~d}$ period, in agreement with previous reports (Greene and Tischler, 1976; Greene, 1978; Gunning et al., 1981; Burstein and Greene, 1982; Ignatius et al., 1985), by $8 \mathrm{~d}$ of NGF treatment the number of cells in the culture incubated with NGF nearly reached a plateau of growth, confirming that NGF inhibited cell proliferation during PC12 cell differentiation (data not shown). The first effects of NGF on growth rate were seen at $3-6 \mathrm{~d}$ of treatment. The PC12 cells also extended neurites, a characteristic of neuronal differentiation, only in the NGF-treated culture. Although after the first day of exposure to NGF only $10 \%$ of the cells extended neurites, by day 8 of NGF treatment almost all cells $(95 \%)$ bore neurites two cell 

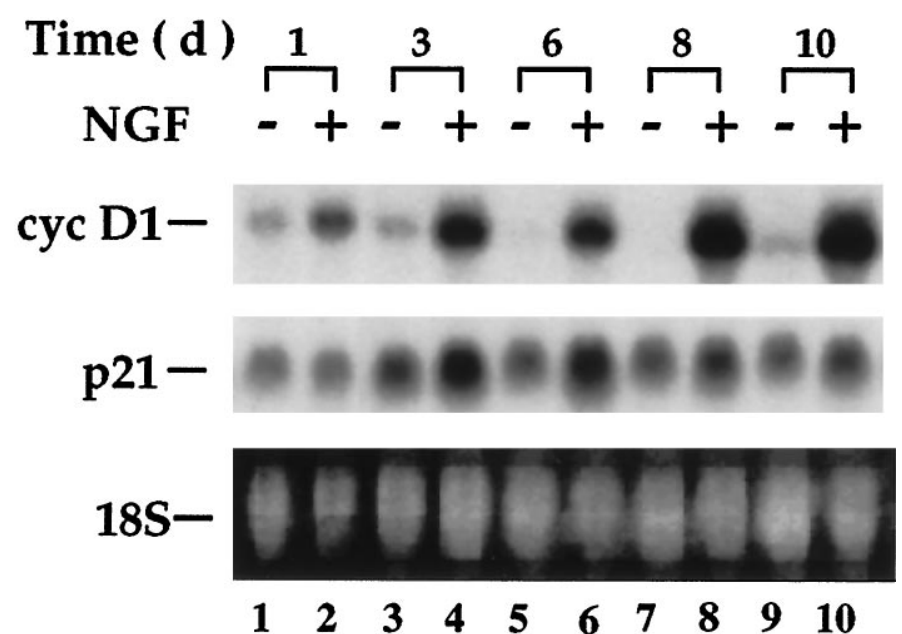

Figure 1. Expression of p21 and cyclin D1 mRNA in PC12 cells during NGF treatment. PC12 cells were plated and cultured in the absence of NGF (lanes 1, 3, 5, 7, 9) or in the presence of NGF (lanes 2, 4, 6, 8, 10) for various lengths of time. Total RNA samples $(15 \mu \mathrm{g} / \mathrm{lane})$ from NGF treated and untreated PC12 cells were separated by formaldehyde gel electrophoresis, photographed after ethidium staining to visualize ribosomal RNA, and transferred to a nylon membrane. The blots were hybridized with human p21 cDNA or mouse cyclin D1 cDNA probes, respectively.

diameters in length. We conclude that all of the cells in the culture were responsive to NGF and that $\sim 3-6 \mathrm{~d}$ of exposure of $\mathrm{PC} 12$ cells to NGF is required before cells enter their final round of cell cycling.

We have previously reported that NGF but not EGF elevates the levels of the p21 and cyclin D1 proteins in PC12 cells (Yan and Ziff, 1995). In Figure 1, Northern analysis of mRNA from NGF-treated PC12 cells confirmed that the corresponding messenger RNAs are also induced by NGF, consistent with NGF transcriptional regulation of the p21 and cyclin D1 genes. Cyclin D1 mRNA was induced at the shortest time point analyzed, $1 \mathrm{~d}$, and p21 mRNA levels were increased at 1-3 d. The induction of cyclin D1 mRNA persisted through the longest time point, $10 \mathrm{~d}$, which is consistent with persistent elevation of the cyclin D1 protein (Yan and Ziff, 1995). The p21 mRNA, however, began to decline after $6 \mathrm{~d}$ of treatment. Also, significant basal levels of p21 mRNA were observed in control cultures lacking NGF.

\section{NGF stimulates the p21 and cyclin D1 promoters through Sp1 binding sites}

To confirm transcriptional regulation by NGF and to deduce the promoter elements activated by NGF, we analyzed the responses to NGF of the cloned p21 and cyclin D1 promoters when they were transiently introduced into PC12 cells in plasmids. In plasmid p21p-Luc, the $2.4 \mathrm{~kb} \mathrm{5'} \mathrm{flanking} \mathrm{region} \mathrm{of} \mathrm{the} \mathrm{human} \mathrm{p21}$ gene, which includes the p53 binding site located at $-2.3 \mathrm{~kb}$, drives the expression of a luciferase reporter gene. Plasmid p21pLuc was introduced into PC12 cells by lipofection together with the plasmid RSV- $\beta$-gal, whose expression of $\beta$-galactosidase provided an internal control for transfection efficiency. The transfected cells were either stimulated with NGF for $2.5 \mathrm{~d}$ or left unstimulated, or they were stimulated with EGF. NGF induced p21-Luc activity 8.3-fold relative to the control, whereas EGF induced only 1.5-fold (Fig. $2 A$ ). The control plasmid RSV-Luc was unresponsive to both EGF and NGF. Increases of the concentration of NGF induced progressively greater activities of the

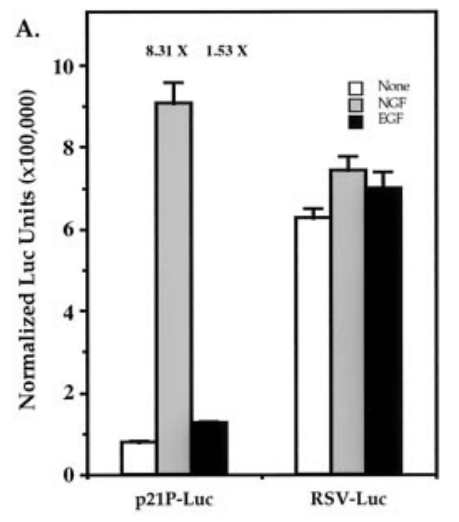

B.

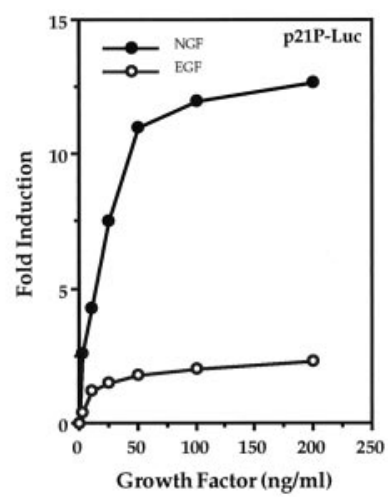

Figure 2. NGF regulation of transfected promoter-Luc constructs. $A$, PC12 cells were transfected with the indicated constructs, incubated for $2.5 \mathrm{~d}$ with or without NGF (50 ng/ml) or EGF (10 ng/ml), and assayed for luciferase activity. RSV- $\beta$ gal was used as an internal control for transfection efficiency. The level of growth factor-induced activity relative to the uninduced control is indicated. The results are from two separate transfections in two independent experiments. $B$, PC12 cells were transfected with the p21p-Luc construct and incubated with various concentrations of NGF or EGF ( 0 to $200 \mathrm{ng} / \mathrm{ml}$ ) as indicated. The fold induction was determined by comparing luciferase activity in transfected cells treated with NGF or EGF with transfected cells without NGF or EGF. The results of a single titration experiment are shown.

p21 promoter, which reached 13-fold stimulation at $200 \mathrm{ng} \mathrm{NGF/}$ ml. Similar increases of EGF stimulated only twofold (Fig. 2B). These effects of NGF and EGF on the transfected p21 promoter reproduced the effects of the growth factors on the endogenous p21 gene seen in PC12 (Fig. 1) (Yan and Ziff, 1995).

To identify the DNA elements activated by NGF in the p21 promoter, we determined the responses to NGF of a series of promoter $5^{\prime}$ truncation mutants. Figure 3 shows that deletion from p21P-Luc of the 1300 nucleotides distal to the promoter, a region that includes the p53 binding site, to yield plasmid p21 1 1.1-Luc with $1.1 \mathrm{~kb}$ of flanking DNA modestly reduced the NGF response but did not change the extent of NGF induction relative to basal or EGF-induced activity. In plasmid p21PSma, an additional 988 residues, including one promoter distal Sp1 site from a cluster of $6 \mathrm{Sp} 1$ sites between residues -120 and -52 , have been deleted. The absolute activity of the promoter diminished approximately twofold, and the NGF induction was reduced from 8.2-fold to 6.2-fold. This indicated that the NGF response depended modestly on sequences between -2400 and -112 ; however, deletion of residues -112 and -61 in plasmid p21PSma $\Delta 1$, a region that contains three additional $\mathrm{Sp} 1$ sites, abolished the NGF response (1.4-fold). This implicated the cluster of Sp1 sites in the mechanism of response to NGF. In confirmation, plasmid p21PSma $\Delta 2$-Luc, in which only residues -112 and -62 , a region that encompasses the second, third, and fourth promoter Sp1 sites, have been deleted from the -2400 nucleotide flanking region, responded only 2.6-fold NGF. These results indicate that both the NGF responsiveness and basal activity of the p21 promoter in PC12 cells were directly related to the number of Sp1 sites retained in the test plasmid from the six-site cluster located proximal to the TATA box.

To investigate NGF regulation of the cyclin D1 promoter, we

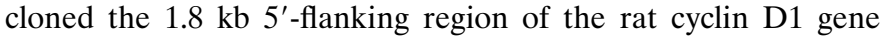
(1660 bp of this sequence have been deposited in GenBank). As seen in Figure $4 A$, NGF stimulated this promoter in plasmid 


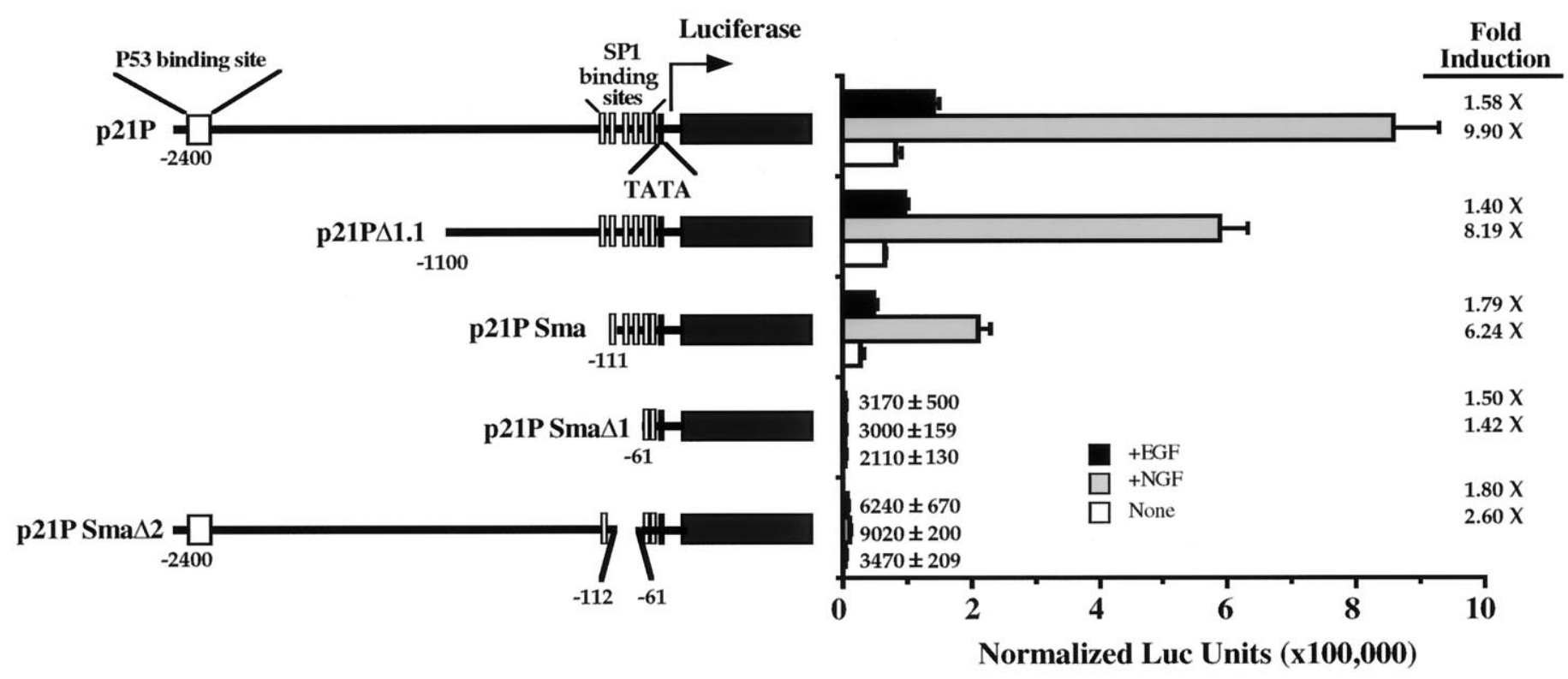

Figure 3. Analysis by deletion mutation of human p21 promoter NGF response regions. PC12 cells transfected with the indicated constructs were incubated with or without NGF or EGF, as described in Figure $2 A$, and then assayed for luciferase activity. The fold induction by growth factor relative to an untreated control is shown. The bars represent the average results of two separate transfections in three independent experiments. The average basal (without NGF or EGF) expression levels for the p21-Luc constructs (normalized luciferase units) were p21p, 83300; p21p $\Delta 1.1,64060$; $21 \mathrm{psma}$, 28380; p21psma $\Delta 1,2110$; and p21psma $\Delta 2,3470$. The sequence locations of the two promoter distal sites of the six Sp1 site cluster are given in Biggs et al. (1996), and the locations of the four promoter proximal sites in Datto et al. (1995b).

prCD1-1810 4.8-fold, whereas EGF stimulated only 1.5-fold. Further deletions revealed an NGF-responsive positive regulatory region between residues -1810 and -916 (see plasmids prCD11414 and prCD1-916), a negative regulatory element between residues -916 and -450 (see plasmid prCD1-450), and an additional positive regulatory element between -450 and -70 (see plasmid prCD1-70). The activity provided by these regions was not under NGF control, because the deletions affected the NGFinduced and basal activities similarly. Indeed, plasmid prCD1-70, which contains only 70 residues of the $5^{\prime}$ flanking region, was stimulated to a greater extent by NGF, 7.8 -fold, than the plasmid prCD1-1810, which retains 1810 residues, 4.8-fold. The deletion of residues -70 to -10 in plasmid prCD1-10, however, eliminated the response to NGF, reducing induction to 1.1 -fold. Figure $4 B$ compares the sequence of this region with the corresponding region of the human cyclin D1 promoter. Both the human and the rat promoters contain two $\mathrm{Sp} 1$ binding sites in this region. The lack of response of plasmid prCD1-450 $\Delta$ to NGF, which contains 450 flanking residues but lacks the $\mathrm{Sp} 1$ site cluster, confirmed that induction by NGF requires the 60 nucleotides containing the Sp1 sites. Deletion of the cluster eliminated the differential effect of NGF and reduced the absolute level of the NGF-induced activity 19-fold relative to prCD1-450. This experiment implicates the cluster of two Sp1 sites in NGF-specific transcriptional control of the rat cyclin D1 promoter.

\section{NGF activates the Sp1 transcription factor}

To determine whether Sp1 sites were sufficient to direct an NGF response, in Figure $5 A$ we assayed plasmids G3TI-Luc and G6TILuc, which contain three and six upstream Sp1 binding sites, respectively, linked to a core promoter with a synthetic TATA box plus an initiator element. These plasmids were stimulated 6.0and 5.9-fold, respectively, by NGF but only 1.3 -fold by EGF. The control plasmid GTI-Luc, which lacks Sp1 sites, was stimulated only 1.9 -fold by NGF. In Figure $5 B$, the level of induction of G3TI-Luc increased progressively with increasing concentrations of NGF, whereas increases of EGF induced only modest changes. Taken together, these results confirmed that three Sp1 binding sites are sufficient to confer NGF-specific responsiveness on a core promoter.

We next analyzed the mechanism of stimulation by NGF. If NGF induced Sp1-dependent transcription by elevating either Sp1 protein levels or Sp1 DNA binding affinity, the induction by NGF would be reproduced by expression of exogenous Sp1 protein. To test this possibility, we determined the responses of the $\mathrm{p} 21$, cyclin $\mathrm{D} 1$, and multiple $\mathrm{Sp} 1$ site promoters to $\mathrm{Sp} 1$ protein expressed from the vector RSV-Sp1, with and without stimulation by NGF or EGF. Expression of $\mathrm{Sp} 1$ protein raised the basal activities of all three promoters (Fig. $6 A-C$ ), suggesting that the cellular levels of Sp1 did not fully saturate the transfected plasmids. In each case, NGF provided a further increase in the activity of the transfected promoters observed in the presence of exogenous Sp1. The extent of the induction of activity by NGF relative to the basal activity was similar in the presence or absence of exogenous Sp1. This suggested that the activity induced by NGF was over and above that provided by increasing $\mathrm{Sp} 1$ levels, indicating that it resulted from a mechanism other than increasing Sp1 levels or DNA binding. Western blotting and electrophoretic mobility shift experiments confirmed that NGF did not induce Sp1 protein expression or DNA binding affinity (see below). These effects of Sp1 and NGF were specific in as much as the Rous Sarcoma Virus (RSV) long terminal repeat in plasmid RSV-Luc did not respond to NGF, EGF, or Sp1 (Fig. 6D).

\section{NGF activates the Sp1 transactivation domain}

To determine whether NGF regulates the Sp1 transactivation domain, we assayed the effects of NGF on the activity of a chimeric protein, Gal4-Sp1, in which the $\mathrm{Sp} 1$ transactivation 
A.
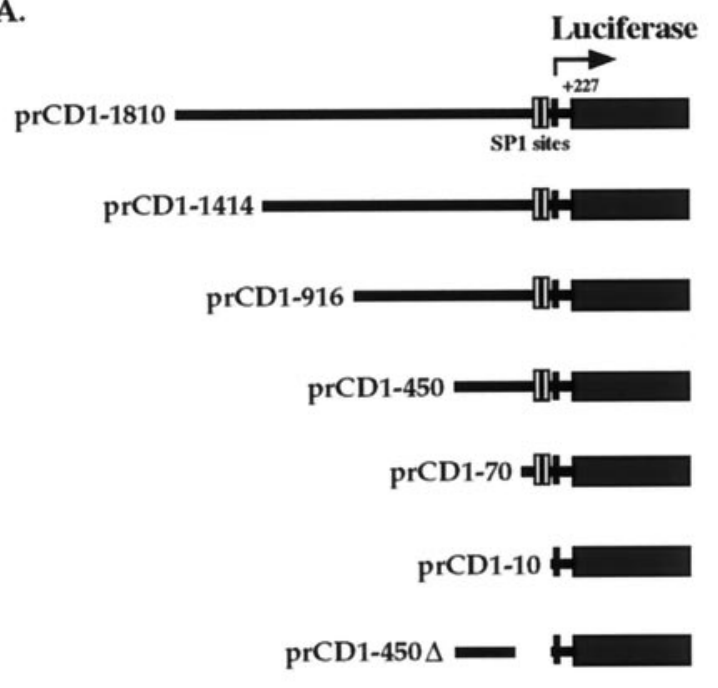

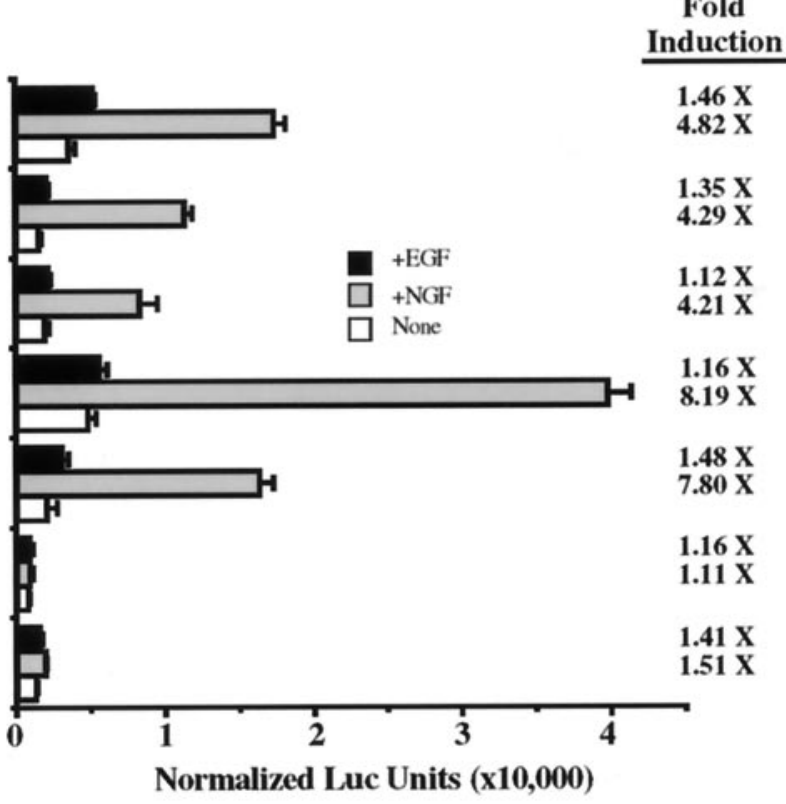

B.

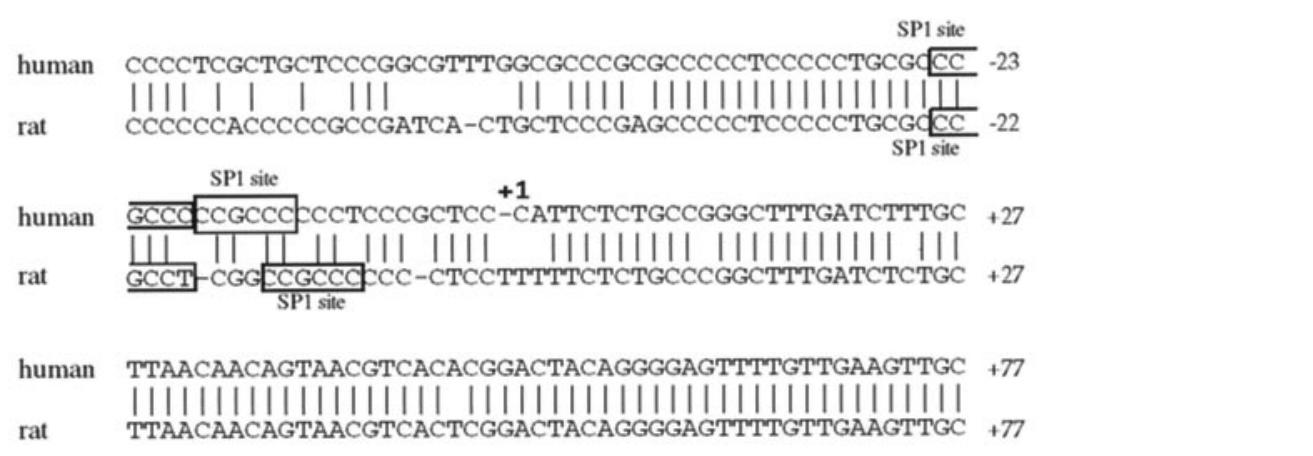

Figure 4. Analysis by deletion mutation of the rat cyclin D1 promoter NGF response region. $A$, PC12 cells transfected with the indicated deletion constructs were incubated with or without NGF or EGF, as described in Figure $2 A$. The luciferase activity was measured. The bars represent the average results of two separate transfections in three independent experiments. The average basal expression levels (without NGF or EGF) for the cyclin D1-Luc constructs (normalized luciferase units) were prCD1-1810, 3480; prcD1-1414, 1490; prCD1-916, 1860; prCD1-450, 4800; prCD1-70, 2600; prCD1-10, 750 ; and prCD1-450, 1200 . B, Alignment of human and rat cyclin D1 proximal promoter sequences between -77 and +77 . Two Sp1 consensus binding sites in the human cyclin D1 promoter and the rat cyclin D1 promoter are indicated.

domain is fused to the Gal4 DNA binding domain. In Figure 7, the reporter plasmid G5B-CAT, in which five Gal4 DNA binding sites are linked to the E1B TATA box, was stimulated 5.7-fold by NGF in the presence of the chimeric Gal4-Sp1 transactivator but only 1.1-fold in the presence of a control Gal4 DNA binding domain protein lacking the Sp1 transactivation domain. In neither case did the reporter respond significantly to EGF. This experiment demonstrated that the transactivation domain of Sp1 is sufficient for NGF stimulation.

Sp1 is one member of a family of factors that binds to the Sp1 DNA site. This includes Sp2, Sp3, and Sp4 as well as Sp1 itself (Kadonaga et al., 1987; Kingsley and Winoto, 1992; Hagen et al., 1995). To determine whether NGF induces transcription by altering the proteins that bind to $\mathrm{Sp} 1$ sites, we compared protein-DNA complexes formed between an Sp1 site oligonucleotide and nuclear extracts of $\mathrm{PC} 12$ cells treated with NGF. At $3 \mathrm{~d}$ of stimulation, a time when NGF has induced the cyclin D1 and $\mathrm{p} 21$ promoter activities and protein levels (Yan and Ziff, 1995), we observed a series of complexes $(A-F)$ shown in Figure $8 A$. Similar complexes were also observed with extracts from unstimulated cells (lanes 1-3) and with cells treated with NGF (lanes 4-6). Each complex was specifically competed by an unlabeled wild-type Sp1 site oligonucleotide but not by a mutant. Complex A is the most prominent complex formed by extracts from cells treated for $3 \mathrm{~d}$ with NGF, as well as by extracts from control cells. We investigated the protein components of this complex further. In Figure $8 B$, complex A was supershifted by a polyclonal antibody specific for the Sp1 protein but not by a control anti-Rb protein antibody (lanes $1-3)$. This indicated that complex A consists of Sp1 protein bound to the Sp1 site oligonucleotide. Complex A comigrated with a complex formed by recombinant human $\mathrm{Sp} 1$ protein (lane 4), suggesting that $\mathrm{Sp} 1$ was the sole protein component in complex A. It also comigrated with a complex formed by $\mathrm{HeLa}$ cell extract with the $\mathrm{Sp} 1$ site oligonucleotide that was sensitive to the Sp1 antibody but not the RB antibody. We also assayed for changes in Sp1 protein levels induced by NGF, using Western analysis. In Figure $8 C$, after 1 and 3 d of NGF treatment, or as controls, after incubation with EGF or without any growth factor, PC12 cells contained comparable levels of $\mathrm{Sp} 1$ as revealed by Western blotting with anti-Sp1 antibody (lanes 1-6). This confirmed that treatment with NGF did not 
A.

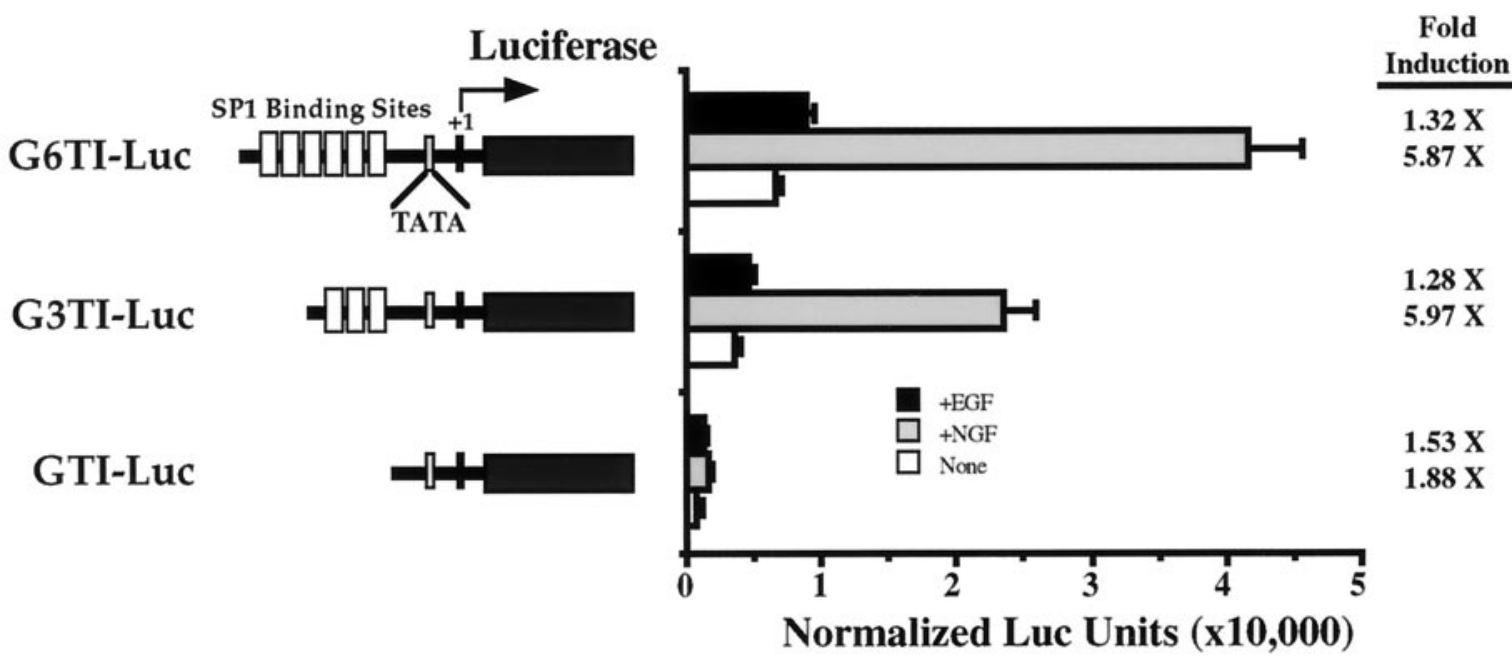

B.

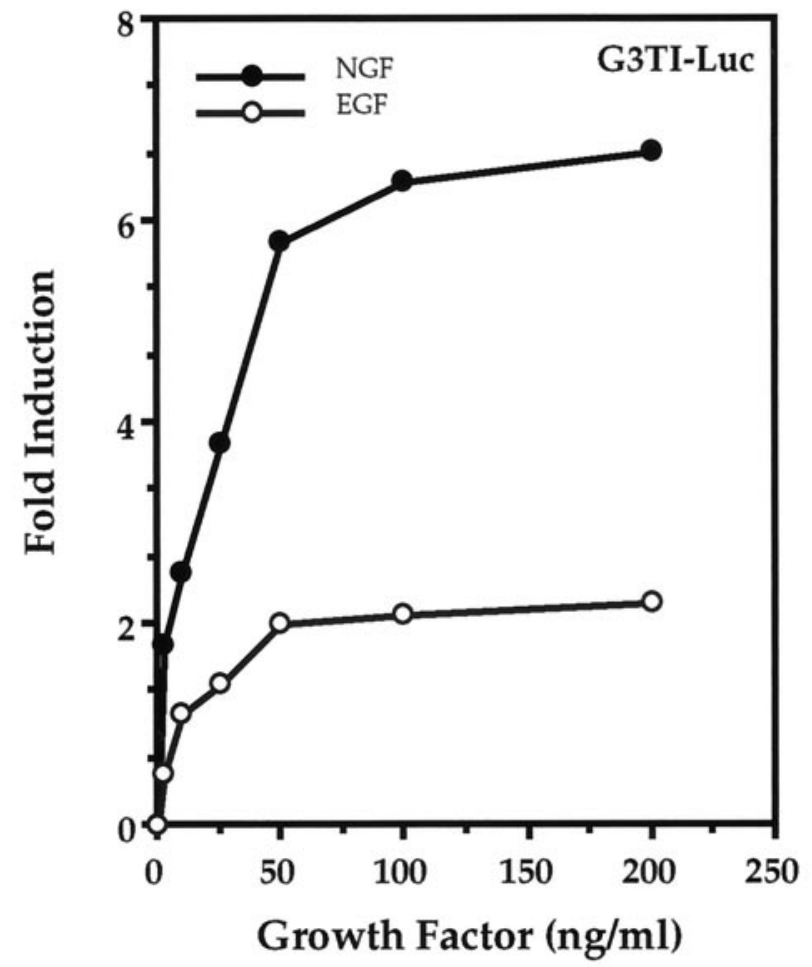

Figure 5. Ability of Sp1 binding sites to confer NGF responsiveness on a minimal promoter construct. $A$, PC12 cells transfected with the indicated constructs were incubated with or without NGF or EGF, as described in Figure $2 A$, and assayed for luciferase activity. The bars represent the average results of two separate transfections in two independent experiments. $B$, PC12 cells were transfected with the plasmid G3TI-Luc and incubated with various concentrations of NGF or EGF as indicated. The fold induction was determined by comparing luciferase activity in transfected cells stimulated with NGF or EGF with the activity of unstimulated transfected cells. The results of a single transfection experiment are presented.

alter Sp1 levels. We conclude that $\mathrm{Sp} 1$ is the major protein in extracts from control and $3 \mathrm{~d}$ NGF-treated cells that binds to Sp1 sites.

\section{DISCUSSION}

We show that NGF induces the transcription of two cell cycle regulatory genes, the $\mathrm{p} 21$ gene and the cyclin $\mathrm{D} 1$ gene. The induction is specific for NGF in as much as EGF, a weak mitogen, failed to induce. The induction of the p21 gene has been studied most extensively in the case of p53-induced growth arrest (El-Deiry et al., 1993; Dulic et al., 1994). The p53 tumor suppressor protein transactivates the p21 promoter through a site $\sim 2000$ residues distal to the transcription start (El-Deiry et al., 1993). NGF is capable of inducing p21 inde- 
A.

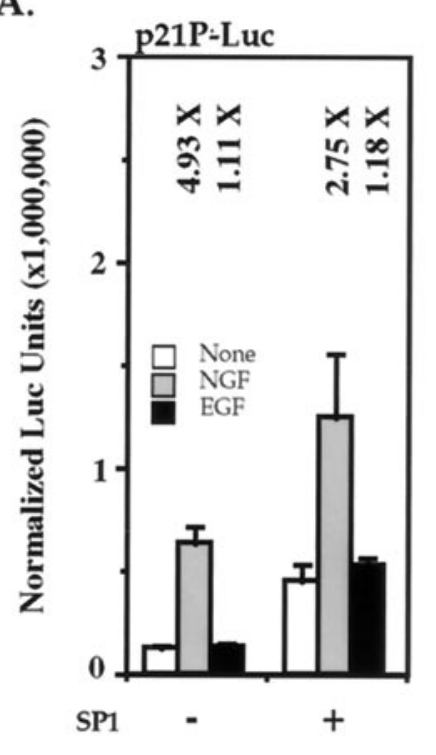

C.

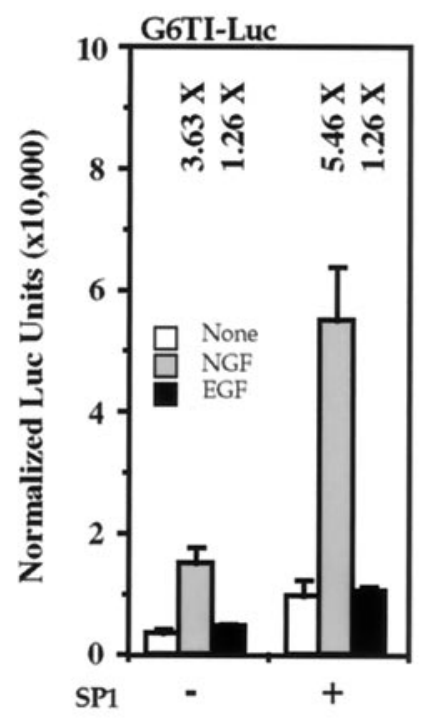

B.

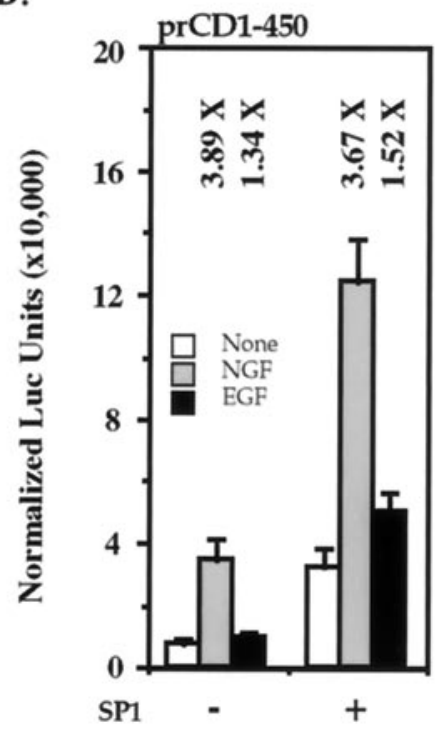

D.

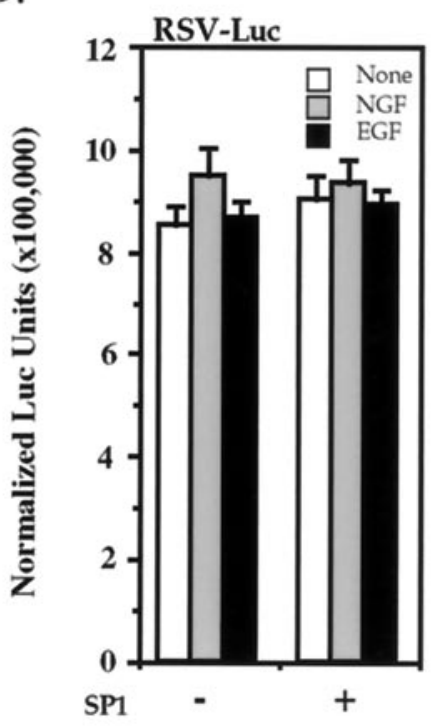

Figure 6. Stimulation of the p21 and cyclin D1 promoters by $\mathrm{Sp} 1$ and NGF. Constructs p21p-luc $(A)$, prCD1-450 $(B)$, G6TI-Luc $(C)$, and RSVLuc $(D)$ were cotransfected with either $5 \mu \mathrm{g}$ of a control vector or $5 \mu \mathrm{g}$ of RSV-Sp1 expression vector, and incubated with or without NGF or EGF, as described in Figure $2 A$. The results are representative of two separate transfections in three independent experiments. pendently of the p53 pathway, because deletion of the p53 binding site did not impair induction. Other examples of p53 independent control of p21 have been described (Jiang et al., 1994; Steinman et al., 1994; Datto et al., 1995b; Macleod et al., 1995; Parker et al., 1995; Akagi et al., 1996; Li et al., 1996; Y. Liu et al., 1996). The p53 protein, however, may have other roles in the mechanism of NGF-induced differentiation of PC12 cells (Eizenberg et al., 1996). The cyclin D1 gene is expressed in many cells in response to mitogens and can enable cells to cross a $\mathrm{G} 1$ restriction point (for review, see Sherr, 1995).

\section{NGF activates the p21 and cyclin D1 promoters via Sp1}

We show that NGF activates transcription via Sp1, a transcription factor that contains a zinc finger DNA binding domain and a bipartite transactivation domain consisting of glutamine-rich regions (Courey and Tjian, 1988; Courey et al., 1989) and that interacts with two TAF proteins, dTAFII110 (Hoey et al., 1993; Gill et al., 1994) and hTAFII55 (Chiang and Roeder, 1995). Although Sp1 is linked to housekeeping gene expression, this gene class is not well defined (Datto et al., 1995b). The persistent activation (for days) of the p21 and cyclin D1 genes by NGF may place these genes in the "housekeeping" category. Sp1 also contributes to the regulation of transcription of a number of neuronspecific genes (Elder et al., 1992; Hahn et al., 1992; Chin et al., 1994; Faraonio et al., 1994; Kallunki et al., 1995; Reeben et al., 1995; Ryabinin et al., 1995; Cibelli et al., 1996).

Several experiments confirm that $\mathrm{Sp} 1$ is activated by NGF. Deletion of the $\mathrm{Sp} 1$ clusters eliminated induction by NGF. Also, 


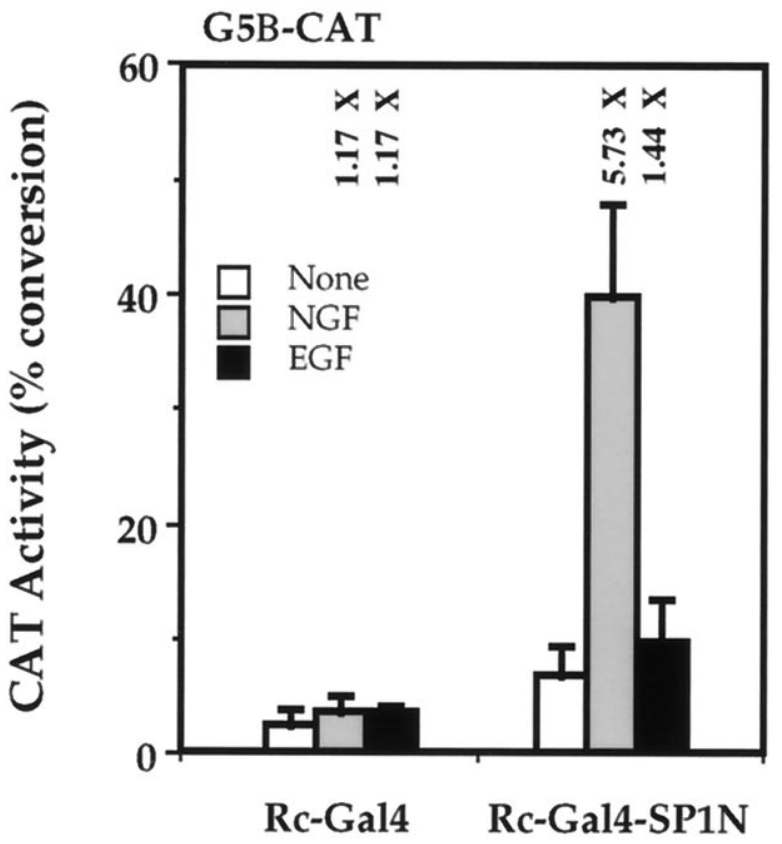

Figure 7. Stimulation by NGF of the Sp1 transactivation domain. Five micrograms of G5BCAT, which contains five Gal4 binding sites upstream of the E1B TATA box, and $5 \mu \mathrm{g}$ of either Rc-Gal4 or Rc-Gal4-sp1N, which encodes the Gal4 DNA binding domain or a chimeric fusion of this domain, respectively, with the $\mathrm{Sp} 1$ transactivation domain were cotransfected into PC12 cells and incubated with or without NGF or EGF, as described in Figure $2 A$, and then harvested for assay of CAT activity. The results are representative of the average two separate transfections in two independent experiments.

NGF activated a promoter composed of multiple Sp1 binding sites linked to a promoter core. NGF also stimulated a Gal4-Sp1 transactivation domain chimera, indicating that NGF augments the function of the Sp1 transactivation domain. Sp1 is likely to be the major factor activated in PC12 cells, in as much as Sp1 is the major protein in nuclear extracts from the NGF-treated cells that forms a complex with an Sp1 site oligonucleotide. Sp3, however, induces the p21 promoter during keratinocyte differentiation (Prowse et al., 1997). The Sp1 site cluster functions in $\mathrm{p} 21$ gene induction in U937 cells by okadaic acid and phorbol esters (Biggs et al., 1996) and VitD3 (M. Liu et al., 1996) and by TGF- $\beta$ in HaCaT human keratinocytes (Datto et al., 1995b). A second cell division inhibitor (Cdi) gene, the p15IN K4B gene, the product of which inhibits $\mathrm{Cdk} 4$ and $\mathrm{Cdk} 6$, is activated by TGF $\beta$ via Sp1 sites (Li et al., 1995). Although phosphorylation is implicated during regulation by other agents (Jackson et al., 1990; Vlach et al., 1995), the mechanism of control by NGF is not known. Either $\mathrm{Sp} 1$ itself or a factor that interacts functionally may be modified, and other transcription factors may also contribute. Induction of p21 by NGF involves the p300 transcriptional coactivator (Billon et al., 1996); however, the relationship of p300 to Sp1 is not known. In K562 human leukemia cells, the AP2 transcription factor activates p21 transcription in response to okadaic acid and phorbol esters through the same $\mathrm{Sp} 1$ site region as studied here (Zeng et al., 1997). Although the hypophosphorylated form of Rb can activate Sp1 function (Kim et al., 1992; Udvadia et al., 1995), exogenous $\mathrm{Rb}$ protein did not regulate $\mathrm{p} 21$ or cyclin $\mathrm{D} 1$ promoter activity in our system (G.-Z. Yan and E. B. Ziff, unpublished observations).
A.

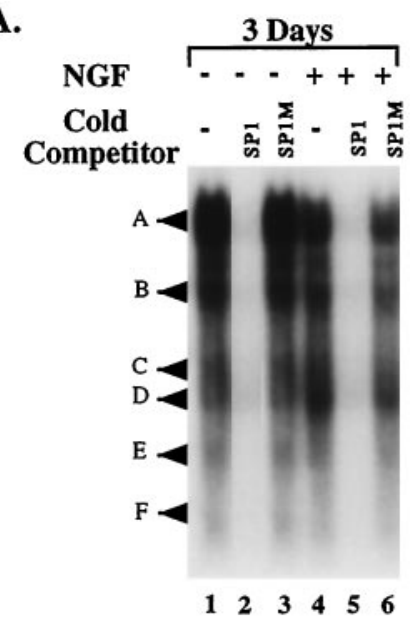

B.

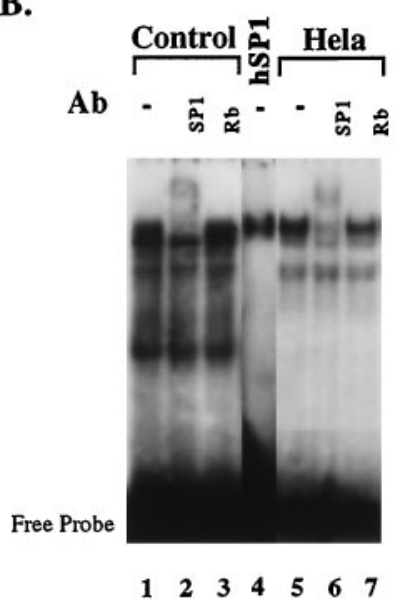

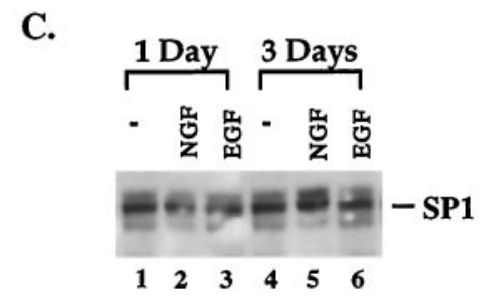

Figure 8. Characterization of DNA-protein complexes by NGF treatment of PC12 cells. A, Competition of Sp1-binding proteins by a $\mathrm{Sp} 1$ oligonucleotide or its mutant. Nuclear extracts were prepared (Dignam et al., 1983) from untreated PC12 cells for $3 \mathrm{~d}$ (lanes 1-3) or from PC12 cells grown in the presence of NGF for $3 \mathrm{~d}$ (lanes 4-6). EMSA analysis was performed with $10 \mu \mathrm{g}$ of nuclear extracts and ${ }^{32} \mathrm{P}$-labeled Sp1 oligonucleotides in the presence of no competitor DNA (lanes 1 and 4), unlabeled Sp1 oligonucleotides (lanes 2 and 5), and unlabeled mutant Sp1 oligonucleotides (Sp1 M) (lanes 3 and 6 ). DNA-protein complexes were resolved on a $4 \%$ nondenaturing polyacrylamide gel. The free probe migrated from the end of the gel. $B$, Analysis of Sp1 site binding proteins by anti-Sp1 antibody supershift and comigration with a recombinant Sp1 DNA complex. EMSA was performed with $10 \mu \mathrm{g}$ of PC12 cell nuclear extracts (lanes 1-3) or purified human Sp1 protein (lane 5) or HeLa nuclear extract (lanes 5-7). Extracts were incubated with $1 \mu$ l of either anti-Sp1 antibody (lanes 2 and 6 ) or anti-Rb antibody (lanes 3 and 7) or without antibody (lanes 1, 4, and 5) for $45 \mathrm{~min}$ before the addition of ${ }^{32} \mathrm{P}$-labeled Sp1 oligonucleotide probe. Autoradiography of lanes 1, 2, and 3 were for $2 \mathrm{hr}$, lane 4 for $4 \mathrm{hr}$, and lanes 5, 6, and 7 for $20 \mathrm{~min}$. $C$, Expression of Sp1 protein in PC12 cells during NGF treatment. PC12 cells were plated and cultured in the presence of NGF (lanes 2 and 5) or EGF (lanes 3 and 6 ) or in the absence of NGF and EGF (lanes 1 and 4 ) for 1 or $3 \mathrm{~d}$. Equal amounts of lysates from NGF treated or EGF treated or untreated PC12 cells $(20 \mu \mathrm{g}$ protein/lane) were separated by $7.5 \%$ SDS-PAGE gels and transferred to nitrocellulose. The blot was probed with anti Sp1-antibody. $\mathrm{Sp} 1$ protein migrated at $95-105 \mathrm{kDa}$.

\section{Consequences of NGF regulation of the p21 and cyclin D1 promoters}

Cyclin D1 is expressed in many cell types as an early response to mitogens, and its aberrant overexpression can be oncogenic rather than growth inhibiting (Jiang et al., 1992, 1993; Juan et al., 1996; Wang et al., 1996). In fibroblasts, elevation of cyclin D1 protein can decrease the length of the $G_{1}$ phase and speed cell entry into the $\mathrm{S}$ phase (Matsushime et al., 1992; Baldin et al., 1993). Therefore, at first consideration, induction of cyclin D1 by NGF during growth arrest seems to be a paradox. Although the current studies do not directly investigate the functions of the p21 and cyclin D1 proteins in PC12, this paradox is partially resolved by reports that 
NGF can be a mitogen during the initial stage of NGF action (Burstein and Greene, 1982). PC12 undergoes one or more rounds of DNA synthesis after NGF treatment (Rudkin et al., 1989) and begins to withdraw from the cell cycle on the third day of NGF stimulation. Cyclin D1 may contribute to PC12 proliferation during the initial stage of NGF treatment.

The arrest of PC12 growth coincides with a later stage of NGF treatment, a time when Cdk activity is inhibited and Cdk protein levels decline (Yan and Ziff, 1995). The decline in Cdk2 activity takes place between 1 and $3 \mathrm{~d}$ of treatment, with $\mathrm{Cdc} 2$ activity declining more slowly (Buchkovich and Ziff, 1994; Dobashi et al., 1995; Yan and Ziff, 1995). Cdk protein levels also decline, a change that takes place for $\mathrm{Cdc} 2$ and $\mathrm{Cdk} 2$ between 3 and $10 \mathrm{~d}$ of treatment. Cdk6 declines at $6 \mathrm{~d}$ of $\mathrm{NGF}$ treatment, and $\mathrm{Cdk} 4$ declines at $8-10 \mathrm{~d}$. Cdk inhibition by p21 and decline in $\mathrm{Cdk}$ protein provide a basis for a barrier to $\mathrm{PC} 12$ proliferation.

The p21 protein forms a physical association with $\mathrm{Cdk} /$ cyclin complexes (Peter and Herskowitz, 1994; Waga et al., 1994) that inhibits Cdk4 and Cdk6 (Bates et al., 1994) and Cdk2 (Harper et al., 1995). Indeed, overexpression of Cdk2 can block PC12 differentiation by NGF (Dobashi et al., 1995). The p21 protein also inhibits the PCNA protein, an essential DNA replication protein (R. Li et al., 1994; Waga et al., 1994; Chen et al., 1995a; Luo et al., 1995). Cdk/cyclin/p21 complexes may exist in both active and inactive forms and are inhibited only when p21 reaches a high stoichiometric ratio (Zhang et al., 1994). The observed delay in the arrest of cycling may reflect a requirement for accumulation of p21 at high, inhibitory levels. The decline in $\mathrm{Cdk}$ proteins may consolidate the block imposed by $\mathrm{p} 21$.

In particular circumstances, cyclin D1 may inhibit proliferation and be compatible with the postmitotic state. Acute expression of cyclin D1 can block fibroblast cycling through interaction with proliferating cell nuclear antigen (Pagano et al., 1994). Senescent fibroblasts contain elevated levels of cyclin D1 in complexes with an inactive, dephosphorylated form of Cdk2 (Dulic et al., 1993). Cyclin D3 is found in differentiating postmitotic myotubes in complexes with inactive forms of $\mathrm{Cdk} 2$ and $\mathrm{Cdk} 4$ (Kiess et al., 1995; Rao and Kohtz, 1995). Significantly, transient expression of cyclin D1 in 6-24 cells, a derivative of PC12 cells that overexpresses the trk-A receptor for NGF, decreased the population of S phase cells (Yan and Ziff, 1995), and cyclin D1 may contribute to the antimitogenic effects of NGF in PC12 cells in the presence of serum (van Grunsven et al., 1996a). Cyclin D1 is expressed in differentiating cells in the developing CNS (Sicinski et al., 1995) and in mature brain (Tamaru et al., 1993), including cells of the external granular layer (EGL) of the cerebellum (Shambaugh et al., 1996). Postmitotic cells of the EGL also express cyclin D2 (Ross et al., 1996). Cyclin D1 is also expressed in sympathetic neurons undergoing apoptosis after NGF withdrawal (Freeman et al., 1994; Kranenburg et al., 1996). In contrast, p21 is required for the survival of differentiating SH-SY5Y neuroblastoma cells (Poluha et al., 1996). Perhaps the cell modulates the effects of p21 and cyclin D1 during differentiation to control the approach to the postmitotic state and the capacity for cell survival. Specific roles for $\mathrm{D}$ type cyclin function in differentiating cells have been proposed (Gao and Zelenka, 1997).

The persistent stimulation of the MAP kinase pathway by NGF relative to EGF may be necessary for the cell to express the high level of p21 required for $\mathrm{Cdk}$ inhibition. Indeed, activation of the MAP kinase pathway is sufficient for differentiation of PC12 cells (Cowley et al., 1994). Cyclin D1 expression is also induced by the p42/p44 ${ }^{\text {MARK }}$ pathway (Lavoie et al., 1996). The mechanism by which the NGF activates Sp1 sites is not yet known. Because the MAP kinase pathway most commonly stimulates proliferation, the capacity for Sp1 site activation may be a specialized aspect of PC12 cells or of terminally differentiating neurons. If so, establishment of this pathway may be an important step in the commitment of a precursor cell to terminal differentiation.

\section{REFERENCES}

Akagi M, Yasui W, Akama Y, Yokozaki H, Tahara H, Haruma K, Kajiyama G, Tahara E (1996) Inhibition of cell growth by transforming growth factor beta 1 is associated with p53-independent induction of p21 in gastric carcinoma cells. Jpn J Cancer Res 87:377-384.

Aloe L, Levi MR (1979) Nerve growth factor-induced transformation of immature chromaffin cells in vivo into sympathetic neurons: effect of antiserum to nerve growth factor. Proc Natl Acad Sci USA $76: 1246-1250$.

Anderson DJ, Axel R (1986) A bipotential neuroendocrine precursor whose choice of cell fate is determined by NGF and glucocorticoids. Cell 47:1079-1090.

Baldin V, Lukas J, Marcote MJ, Pagano M, Draetta G (1993) Cyclin D1 is a nuclear protein required for cell cycle progression in G1. Genes Dev 7:812-821.

Bates S, Bonetta L, MacAllan D, Parry D, Holder A, Dickson C, Peters G (1994) CDK6 (PLSTIRE) and CDK4 (PSK-J3) are a distinct subset of the cyclin-dependent kinases that associate with cyclin D1. Oncogene 9:71-79.

Beijersbergen RL, Bernards R (1996) Cell cycle regulation by the retinoblastoma family of growth inhibitory proteins [review]. Biochim Biophys Acta 1287:103-120.

Biggs JR, Kudlow JE, Kraft AS (1996) The role of the transcription factor Sp1 in regulating the expression of the WAF1/CIP1 gene in U937 leukemic cells. J Biol Chem 271:901-906.

Billon N, van Grunsven LA, Rudkin BB (1996) The CDK inhibitor p21WAF1/Cip1 is induced through a p300-dependent mechanism during NGF-mediated neuronal differentiation of PC12 cells. Oncogene 13:2047-2054.

Boonstra J, Moolenaar WH, Harrison PH, Moed P, van der Saag PT, de Laat SW (1983) Ionic responses and growth stimulation induced by nerve growth factor and epidermal growth factor in rat pheochromocytoma (PC12) cells. J Cell Biol 97:92-98.

Boulton TG, Nye SH, Robbins DJ, Ip NY, Radziejewska E, Morgenbesser SD, DePinho RA, Panayotatos N, Cobb MH, Yancopoulos GD (1991) ERKs: a family of protein-serine/threonine kinases that are activated and tyrosine phosphorylated in response to insulin and NGF. Cell 65:663-675.

Boulukos KE, Ziff EB (1993) Adenovirus 5 E1A proteins disrupt the neuronal phenotype and growth factor responsiveness of PC12 cells by a conserved region 1-dependent mechanism. Oncogene 8:237-248.

Buchkovich KJ, Ziff EB (1994) Nerve growth factor regulates the expression and activity of p33cdk2 and p34cdc2 kinases in PC12 pheochromocytoma cells. Mol Biol Cell 5:1225-1241.

Burstein DE, Greene LA (1982) Nerve growth factor has both mitogenic and antimitogenic activity. Dev Biol 94:477-482.

Cathala G, Savoucet J-F, Mendez B, West BL, Karin M, Martial JA, Baxter JD (1983) A method for isolation of intact translationally active ribonucleic acid. DNA 2:329-335.

Chen J, Jackson PK, Kirschner MW, Dutta A (1995a) Separate domains of p21 involved in the inhibition of Cdk kinase and PCNA. Nature 374:386-388.

Chen PL, Riley DJ, Lee WH (1995b) The retinoblastoma protein as a fundamental mediator of growth and differentiation signals [review]. Crit Rev Eukaryot Gene Expr 5:79-95.

Chiang CM, Roeder RG (1995) Cloning of an intrinsic human TFIID subunit that interacts with multiple transcriptional activators. Science 267:531-536.

Chin LS, Li L, Greengard P (1994) Neuron-specific expression of the synapsin II gene is directed by a specific core promoter and upstream regulatory elements. J Biol Chem 269:18507-18513.

Cibelli G, Schoch S, Pajunk H, Brand IA, Thiel G (1996) A (G+C)-rich motif in the aldolase $\mathrm{C}$ promoter functions as a constitutive transcriptional enhancer element. Eur J Biochem 237:311-317.

Courey AJ, Tjian R (1988) Analysis of Sp1 in vivo reveals multiple transcriptional domains, including a novel glutamine-rich activation motif. Cell 55:887-898. 
Courey AJ, Holtzman DA, Jackson SP, Tjian R (1989) Synergistic activation by the glutamine-rich domains of human transcription factor Sp1. Cell 59:827-836.

Cowley S, Paterson H, Kemp P, Marshall CJ (1994) Activation of MAP kinase kinase is necessary and sufficient for PC12 differentiation and for transformation of NIH 3T3 cells. Cell 77:841-852.

Datto MB, Li Y, Panus JF, Howe DJ, Xiong Y, Wang XF (1995a) Transforming growth factor beta induces the cyclin-dependent kinase inhibitor p21 through a p53-independent mechanism. Proc Natl Acad Sci USA 92:5545-5549.

Datto MB, Yu Y, Wang XF (1995b) Functional analysis of the transforming growth factor beta responsive elements in the WAF1/Cip1/p21 promoter. J Biol Chem 270:28623-28628.

Dignam JD, Lebowitz RM, Roeder RG (1983) Accurate transcription initiation by RNA polymerase II is a soluble extract from isolated mammalian nuclei. Nucleic Acids Res 14:1475-1489.

Dobashi Y, Kudoh T, Matsumine A, Toyoshima K, Akiyama T (1995) Constitutive overexpression of CDK2 inhibits neuronal differentiation of rat pheochromocytoma PC12 cells. J Biol Chem 270:23031-23037.

Dulic V, Drullinger LF, Lees E, Reed SI, Stein GH (1993) Altered regulation of $G_{1}$ cyclins in senescent human diploid fibroblasts: accumulation of inactive cyclin E-Cdk2 and cyclin D1-Cdk2 complexes. Proc Natl Acad Sci USA 90:11034-11038.

Dulic V, Kaufmann WK, Wilson SJ, Tlsty TD, Lees E, Harper JW, Elledge SJ, Reed SI (1994) p53-dependent inhibition of cyclindependent kinase activities in human fibroblasts during radiationinduced $\mathrm{G}_{1}$ arrest. Cell 76:1013-1023.

Eizenberg O, Faber EA, Gottlieb E, Oren M, Rotter V, Schwartz M (1996) p53 plays a regulatory role in differentiation and apoptosis of central nervous system-associated cells. Mol Cell Biol 16:5178-5185.

El-Deiry WS, Tokino T, Velculescu VE, Levy DB, Parsons R, Trent JM, Lin D, Mercer WE, Kinzler KW, Vogelstein B (1993) WAF1, a potential mediator of p53 tumor suppression. Cell 75:817-825.

Elder GA, Liang Z, Lee N, Friedrich VJ, Lazzarini RA (1992) Novel DNA binding proteins participate in the regulation of human neurofilament $\mathrm{H}$ gene expression. Brain Res Mol Brain Res 15:85-98.

Faraonio R, Minopoli G, Porcellini A, Costanzo F, Cimino F, Russo T (1994) The DNA sequence encompassing the transcription start site of a TATA-less promoter contains enough information to drive neuronspecific transcription. Nucleic Acids Res 22:4876-4883.

Freeman RS, Estus S, Johnson EJ (1994) Analysis of cell cycle-related gene expression in postmitotic neurons: selective induction of Cyclin D1 during programmed cell death. Neuron 12:343-355.

Gao CY, Zelenka PS (1997) Cyclins, cyclin-dependent kinases and differentiation. BioEssays 19:307-315.

Gill G, Pascal E, Tseng ZH, Tjian R (1994) A glutamine-rich hydrophobic patch in transcription factor Sp1 contacts the dTAFII110 component of the Drosophila TFIID complex and mediates transcriptional activation. Proc Natl Acad Sci USA 91:192-196.

Gizang GE, Ziff EB (1990) Nerve growth factor regulates tyrosine hydroxylase gene transcription through a nucleoprotein complex that contains c-Fos. Genes Dev 4:477-491.

Gomez N, Cohen P (1991) Dissection of the protein kinase cascade by which nerve growth factor activates MAP kinases. Nature 353:170-173.

Gomez N, Tonks NK, Morrison C, Harmar T, Cohen P (1990) Evidence for communication between nerve growth factor and protein tyrosine phosphorylation. FEBS Lett 271:119-122.

Gotoh Y, Nishida E, Yamashita T, Hoshi M, Kawakami M, Sakai H (1990) Microtubule-associated-protein (MAP) kinase activated by nerve growth factor and epidermal growth factor in PC12 cells: identity with the mitogen-activated MAP kinase of fibroblastic cells. Eur J Biochem 193:661-669.

Greenberg ME, Hermanowski AL, Ziff EB (1986) Effect of protein synthesis inhibitors on growth factor activation of c-fos, c-myc, and actin gene transcription. Mol Cell Biol 6:1050-1057.

Greene LA (1978) Nerve growth factor prevents the death and stimulates the neuronal differentiation of clonal PC12 pheochromocytoma cells in serum-free medium. J Cell Biol 78:747-755.

Greene LA, Tischler AS (1976) Establishment of a noradrenergic clonal line of rat adrenal pheochromocytoma cells which respond to nerve growth factor. Proc Natl Acad Sci USA 73:2424-2428.

Gunning PW, Landreth GE, Layer P, Ignatius M, Shooter EM (1981) Nerve growth factor-induced differentiation of PC12 cells: evaluation of changes in RNA and DNA metabolism. J Neurosci 1:368-379.

Hagen G, Dennig J, Preiss A, Beato M, Suske G (1995) Functional analyses of the transcription factor Sp4 reveal properties distinct from Sp1 and Sp3. J Biol Chem 270:24989-24994.

Hahn M, Hahn SL, Stone DM, Joh TH (1992) Cloning of the rat gene encoding choline acetyltransferase, a cholinergic neuron-specific marker. Proc Natl Acad Sci USA 89:4387-4391.

Harper JW, Elledge SJ, Keyomarsi K, Dynlacht B, Tsai LH, Zhang P, Dobrowolski S, Bai C, Connell CL, Swindell E, Fox MP, Wei N (1995) Inhibition of cyclin-dependent kinases by p21. Mol Biol Cell 6:387-400.

Hoey T, Weinzierl RO, Gill G, Chen JL, Dynlacht BD, Tjian R (1993) Molecular cloning and functional analysis of Drosophila TAF110 reveal properties expected of coactivators. Cell 72:247-260.

Ignatius MJ, Chandler CR, Shooter EM (1985) Nerve growth factortreated, neurite-bearing PC12 cells continue to synthesize DNA. J Neurosci 5:343-351.

Jackson SP, MacDonald JJ, Lees MS, Tjian R (1990) GC box binding induces phosphorylation of $\mathrm{Sp} 1$ by a DNA-dependent protein kinase. Cell 63:155-165.

Jiang H, Lin J, Su ZZ, Collart FR, Huberman E, Fisher PB (1994) Induction of differentiation in human promyelocytic HL-60 leukemia cells activates p21, WAF1/CIP1, expression in the absence of p53. Oncogene 9:3397-3406.

Jiang W, Kahn SM, Tomita N, Zhang YJ, Lu SH, Weinstein IB (1992) Amplification and expression of the human cyclin D gene in esophageal cancer. Cancer Res 52:2980-2983.

Jiang W, Kahn SM, Zhou P, Zhang YJ, Cacace AM, Infante AS, Doi S, Santella RM, Weinstein IB (1993) Overexpression of cyclin D1 in rat fibroblasts causes abnormalities in growth control, cell cycle progression and gene expression. Oncogene 8:3447-3457.

Juan G, Gong J, Traganos F, Darzynkiewicz Z (1996) Unscheduled expression of cyclins D1 and D3 in human tumour cell lines. Cell Proliferation 29:259-266.

Kadonaga JT, Carner KR, Masiarz FR, Tjian R (1987) Isolation of cDNA encoding transcription factor $\mathrm{Sp} 1$ and functional analysis of the DNA binding domain. Cell 51:1079-1090.

Kallunki P, Jenkinson S, Edelman GM, Jones FS (1995) Silencer elements modulate the expression of the gene for the neuron-glia cell adhesion molecule, Ng-CAM. J Biol Chem 270:21291-21298.

Kiess M, Gill RM, Hamel PA (1995) Expression of the positive regulator of cell cycle progression, cyclin D3, is induced during differentiation of myoblasts into quiescent myotubes. Oncogene 10:159-166.

Kim SJ, Onwuta US, Lee YI, Li R, Botchan MR, Robbins PD (1992) The retinoblastoma gene product regulates Sp1-mediated transcription. Mol Cell Biol 12:2455-2463.

Kingsley C, Winoto A (1992) Cloning of GT box-binding proteins: a novel $\mathrm{Sp} 1$ multigene family regulating $\mathrm{T}$-cell receptor gene expression. Mol Cell Biol 12:4251-4261.

Kranenburg O, van der Eb AJ, Zantema A (1996) Cyclin D1 is an essential mediator of apoptotic neuronal cell death. EMBO J 15:46-54.

Lavoie JN, L'Allemain G, Brunet A, Muller R, Pouyssegur J (1996) Cyclin D1 expression is regulated positively by the $\mathrm{p} 42 / \mathrm{p} 44^{\mathrm{MAPK}}$ pathway. J Biol Chem 271:20608-20616.

Leonard DG, Ziff EB, Green LA (1987) Identification and characterization of mRNAs regulated by nerve growth factor in PC12 cells. Mol Cell Biol 7:3156-3167.

Leonard DG, Gorham JD, Cole P, Greene LA, Ziff EB (1988) A nerve growth factor-regulated messenger RNA encodes a new intermediate filament protein. J Cell Biol 106:181-193.

Li JM, Nichols MA, Chandrasekharan S, Xiong Y, Wang XF (1995) Transforming growth factor beta activates the promoter of cyclindependent kinase inhibitor p15INK4B through an Sp1 consensus site. J Biol Chem 270:26750-26753.

Li LH, Nerlov C, Prendergast G, MacGregor D, Ziff EB (1994) c-Myc represses transcription in vivo by a novel mechanism dependent on the initiator element and Myc box II. EMBO J 13:4070-4079.

Li R, Waga S, Hannon GJ, Beach D, Stillman B (1994) Differential effects by the p21 CDK inhibitor on PCNA-dependent DNA replication and repair. Nature 371:534-537.

Li R, Hannon GJ, Beach D, Stillman B (1996) Subcellular distribution of p21 and PCNA in normal and repair-deficient cells following DNA damage. Curr Biol 6:189-199.

Liu M, Lee MH, Cohen M, Bommakanti M, Freedman LP (1996) Transcriptional activation of the Cdk inhibitor $\mathrm{p} 21$ by vitamin D3 leads to the induced differentiation of the myelomonocytic cell line U937. Genes Dev 10:142-153.

Liu Y, Martindale JL, Gorospe M, Holbrook NJ (1996) Regulation of 
p21WAF1/CIP1 expression through mitogen-activated protein kinase signaling pathway. Cancer Res 56:31-35.

Luo Y, Hurwitz J, Massague J (1995) Cell-cycle inhibition by independent CDK and PCNA binding domains in p21Cip1. Nature 375:159-161.

Macleod KF, Sherry N, Hannon G, Beach D, Tokino T, Kinzler K, Vogelstein B, Jacks T (1995) p53-dependent and independent expression of p21 during cell growth, differentiation, and DNA damage. Genes Dev 9:935-944.

Matsushime H, Roussel MF, Ashmun RA, Sherr CJ (1991) Colonystimulating factor 1 regulates novel cyclins during the G1 phase of the cell cycle. Cell 65:701-713.

Matsushime H, Ewen ME, Strom DK, Kato JY, Hanks SK, Roussel MF, Sherr CJ (1992) Identification and properties of an atypical catalytic subunit (p34PSK-J3/cdk4) for mammalian D type G1 cyclins. Cell 71:323-334.

Pagano M, Theodoras AM, Tam SW, Draetta GF (1994) Cyclin D1mediated inhibition of repair and replicative DNA synthesis in human fibroblasts. Genes Dev 8:1627-1639.

Parker SB, Eichele G, Zhang P, Rawls A, Sands AT, Bradley A, Olson EN, Harper JW, Elledge SJ (1995) p53-independent expression of p21Cip1 in muscle and other terminally differentiating cells. Science 267:1024-1027.

Peter M, Herskowitz I (1994) Joining the complex: cyclin-dependent kinase inhibitory proteins and the cell cycle. Cell 79:181-184.

Poluha W, Poluha DK, Chang B, Crosbie NE, Schonhoff CM, Kilpatrick DL, Ross AH (1996) The cyclin-dependent kinase inhibitor p21 (WAF1) is required for survival of differentiating neuroblastoma cells. Mol Cell Biol 16:1335-1341.

Prowse DM, Bolgan L, Molnar A, Dotto GP (1997) Involvement of the $\mathrm{Sp} 3$ transcription factor in induction of $\mathrm{p} 21 \mathrm{Cip} 1 /$ WAF1 in keratinocyte differentiation. J Biol Chem 272:1308-1314.

Rao SS, Kohtz DS (1995) Positive and negative regulation of D-type cyclin expression in skeletal myoblasts by basic fibroblast growth factor and transforming growth factor beta: a role for cyclin D1 in control of myoblast differentiation. J Biol Chem 270:4093-4100.

Reeben M, Myohanen S, Saarma M, Prydz H (1995) Sequencing of the rat light neurofilament promoter reveals differences in methylation between expressing and non-expressing cell lines, but not tissues. Gene 157:325-329.

Ross ME, Carter ML, Lee JH (1996) MN20, a D2 cyclin, is transiently expressed in selected neural populations during embryogenesis. J Neurosci 16:210-219.

Rudkin BB, Lazarovici P, Levi BZ, Abe Y, Fujita K, Guroff G (1989) Cell cycle-specific action of nerve growth factor in PC12 cells: differentiation without proliferation. EMBO J 8:3319-3325.

Ryabinin AE, Sato TN, Morris PJ, Latchman DS, Wilson MC (1995) Immediate upstream promoter regions required for neurospecific expression of SNAP-25. J Mol Neurosci 6:201-210.

Shambaugh III GE, Lee RJ, Watanabe G, Erfurth F, Karnezis AN, Koch AE, Haines III GK, Halloran M, Brody BA, Pestell RG (1996) Reduced cyclin D1 expression in the cerebella of nutritionally deprived rats correlates with developmental delay and decreased cellular DNA synthesis. J Neuropathol Exp Neurol 55:1009-1020.
Sherr CJ (1995) D-type cyclins. Trends Biochem Sci 20:187-190.

Sicinski P, Donaher JL, Parker SB, Li T, Fazeli A, Gardner H, Haslam SZ, Bronson RT, Elledge SJ, Weinberg RA (1995) Cyclin D1 provides a link between development and oncogenesis in the retina and breast. Cell 82:621-630.

Sif S, Gilmore TD (1994) Interaction of the v-Raf oncoprotein with cellular transcription factor Sp1. J Virol 68:7131-7138.

Soto AM, Sonnenschein C (1985) The role of estrogens on the proliferation of human breast tumor cells (MCF-7). J Steroid Biochem 23:87-94.

Steinman RA, Hoffman B, Iro A, Guillouf C, Liebermann DA, elHouseini ME (1994) Induction of p21 (WAF-1/CIP1) during differentiation. Oncogene 9:3389-3396.

Tamaru T, Trigun SK, Okada M, Nakagawa H (1993) Identification of cells expressing a D type G1 cyclin in matured brain: implication for its role in neuronal function. Neurosci Lett 153:169-172.

Traverse S, Gomez N, Paterson H, Marshall C, Cohen P (1992) Sustained activation of the mitogen-activated protein (MAP) kinase cascade may be required for differentiation of PC12 cells: comparison of the effects of nerve growth factor and epidermal growth factor. Biochem J 288:351-355

Udvadia AJ, Templeton DJ, Horowitz JM (1995) Functional interactions between the retinoblastoma $(\mathrm{Rb})$ protein and Sp-family members: superactivation by $\mathrm{Rb}$ requires amino acids necessary for growth suppression. Proc Natl Acad Sci USA 92:3953-3957.

Unsicker K, Krisch B, Otten U, Thoenen H (1978) Nerve growth factorinduced fiber outgrowth from isolated rat adrenal chromaffin cells: impairment by glucocorticoids. Proc Natl Acad Sci USA 75:3498-3502.

van Grunsven LA, Thomas A, Urdiales JL, Machenaud S, Choler P, Durand I, Rudkin BB (1996a) Nerve growth factor-induced accumulation of PC12 cells expressing cyclin D1: evidence for a $\mathrm{G} 1$ phase block. Oncogene 12:855-862.

van Grunsven LA, Billon N, Savatier P, Thomas A, Urdiales JL, Rudkin BB (1996b) Effect of nerve growth factor on the expression of cell cycle regulatory proteins in PC12 cells: dissection of the neurotrophic response from the anti-mitogenic response. Oncogene 12:1347-1356.

Vlach J, Garcia A, Jacque JM, Rodriguez MS, Michelson S, Virelizier JL (1995) Induction of Sp1 phosphorylation and NF-kappa B-independent HIV promoter domain activity in T lymphocytes stimulated by okadaic acid. Virology 208:753-761.

Waga S, Hannon GJ, Beach D, Stillman B (1994) The p21 inhibitor of cyclin-dependent kinases controls DNA replication by interaction with PCNA. Nature 369:574-578.

Wang OS, Sabourin CL, Wang H, Stoner GD (1996) Overexpression of cyclin D1 and cyclin $\mathrm{E}$ in $N$-nitrosomethylbenzylamine-induced rat esophageal tumorigenesis. Carcinogenesis 17:1583-1588.

Yan GZ, Ziff EB (1995) NGF regulates the PC12 cell cycle machinery through specific inhibition of the Cdk kinases and induction of cyclin D1. J Neurosci 15:6200-6212.

Zeng YX, Somasundaram K, el-Deiry WS (1997) AP2 inhibits cancer cell growth and activates p21WAF1/CIP1 expression. Nat Genet 15:78-82.

Zhang H, Hannon GJ, Beach D (1994) p21-containing cyclin kinases exist in both active and inactive states. Genes Dev 8:1750-1758. 